\title{
SIZE AND SHAPE VARIABILITY IN THE SKULL OF PONTOPORIA BLAINVILLEI (CETACEA: PONTOPORIIDAE) FROM THE BRAZILIAN COAST
}

\author{
Alessandra Higa ${ }^{1,2}$, Erika Hingst-Zaher ${ }^{2}$ and Mario de Vivo ${ }^{2}$
}

\begin{abstract}
The existence of sexual dimorphism in Pontoporia blainvillei has long been known, with females being larger than males. However, no study so far has explored this dimorphism separately in its size and shape components. Here we analyse sexual dimorphism present in eight linear measurements of the skulls of 56 specimens ( 30 females and 26 males) of P. blainvillei from several localities along the Brazilian coast. We also investigate the sexual dimorphism in size and shape using geometric morphometric techniques, employing a subsample of the specimens above consisting of 27 skulls (12 females and 15 males). The analysis was based on landmarks digitized in four views of the skull: dorsal, ventral, lateral and occipital. A PCA showed the existence of two distinct populations, thus requiring the separation of two samples for the analysis of the effects of sexual dimorphism. Results of traditional and geometric morphometrics analyses revealed no sexual dimorphism in shape. All differences observed between the sexes are size related, with females bigger than males. Shape, however, is an important factor in the differentiation of at least two populations of this species.
\end{abstract}

Resumo - A existência de dimorfismo sexual em Pontoporia blainvillei é reconhecida há algum tempo, sendo as fêmeas maiores que os machos. Entretanto, nenhum estudo explorou este dimorfismo analisando seus componentes de tamanho e forma separadamente. Neste estudo, analisamos o dimorfismo sexual presente através de oito medidas lineares dos crânios de 56 espécimes (30 fêmeas e 26 machos) de P. blainvillei provenientes de distintas localidades ao longo da costa brasileira. Estudamos também o dimorfismo no tamanho e na forma utilizando técnicas de morfometria geométrica, empregando uma subamostra dos espécimes acima, consistindo em 27 crânios (12 fêmeas e 15 machos). As análises foram baseadas em marcos anatômicos digitalizados em quatro vistas do crânio: dorsal, ventral, lateral e occipital. A ACP mostrou a existência de duas populações distintas, requerendo, assim, a separação dessas amostras para as análises dos efeitos do dimorfismo sexual. Os resultados das análises da morfometria tradicional e geométrica revelaram que não existe dimorfismo sexual na forma. Todas as diferenças observadas entre os sexos estão relacionadas ao tamanho, com fêmeas maiores que machos. A forma, no entanto, é um fator importante na diferenciação de pelo menos duas populações desta espécie.

Keywords: Pontoporia blainvillei, franciscana, sexual dimorphism, morphometrics, geometric morphometrics.

\section{Introduction}

The franciscana, Pontoporia blainvillei (Gervais and d'Orbigny, 1844), occurs in coastal waters of South America, from eastern Brazil to Argentina. Its known distribution extends from Itaúnas, Espírito Santo State (ES), Brazil, at $18^{\circ} 25^{\prime}$ S (Moreira and Siciliano, 1991) to Golfo Nuevo, Península Valdés in Chubut Province, Argentina, at $42^{\circ} 35^{\prime} \mathrm{S}$ (Crespo et al., 1998). Pinedo $(1991,1995)$ indicated the existence of two distinct populations, based on morphological and morphometric characters. Such populations occurred, respectively, to the north and to the south of the Brazilian state of Santa Catarina. The same pattern was reported by Secchi et al. (1998), employing mtDNA sequencing. Reports on sexual dimorphism in this genus have been published long before the description of its geographic variation. Lahille (1899) was the first to point out the existence of sexual dimorphism in Pontoporia, albeit only as measurements presented in a table, showing that females are larger than males. Other authors such as Cabrera and Yepes (1940) and Pilleri (1971) reported the same, but no statistical analysis was available. Kasuya and Brownell (1979) examined specimens from Uruguay and discussed the existence of sexual differences in growth rates, with males having slower rates than females, but keeping the same size/weight ratios. Finally, Pinedo $(1991,1995)$ presented relevant statistical analysis, employing both external and cranial measurements, concluding that females were larger than males. Ramos (1997) and Ramos et al. (2000) confirmed this observation for specimens from northern Rio de Janeiro, Brazil.

Though sexual dimorphism in size has been extensively demonstrated, the presence of sexual dimorphism in the shape independently of size has never been studied. Thus, the objective of this paper is to explore the nature of sexual dimorphism in P. blainvillei in relation to both form components (size and shape), and whether differences between males and females follow the same patterns along the geographic range studied.

\section{Material and Methods}

We examined specimens of P. blainvillei from different localities in Brazil, as shown in Figure 1. A list of specimens examined is given in the Appendix.

We selected only adult specimens with known sexes. For the specimens with postcranial skeleton, their age classes were determined by the degree of fusion of all epiphyses to vertebrae centra. When only skulls were available, the degree of fusion of skull sutures and total bone alveolar separation throughout the tooth rows was employed as an age criteria (Perrin, 1975; Kasuya and Brownell, 1979; Pinedo, 1991). All specimens from Cananéia and Superagui (localities 4 and 5, see Figure 1) had their ages known (ages above 5 years; F. Rosas, INPA, Manaus, Brazil, unpublished data).

For the analysis of differences between sexes related to size and shape of the skull, we used both traditional (Marcus, 1990) and geometric morphometrics (see Bookstein, 1991, 1996; Marcus et al., 1993; Rohlf and

\footnotetext{
Faculdade de Filosofia, Ciências e Letras de Ribeirão Preto, Universidade de São Paulo (FFCLRP-USP). Corresponding author: alehiga@usp.br.

${ }^{2}$ Mastozoologia, Museu de Zoologia da Universidade de São Paulo (MZUSP) Cx. P. 42694, São Paulo, SP, Brazil, 04299-970.
} 


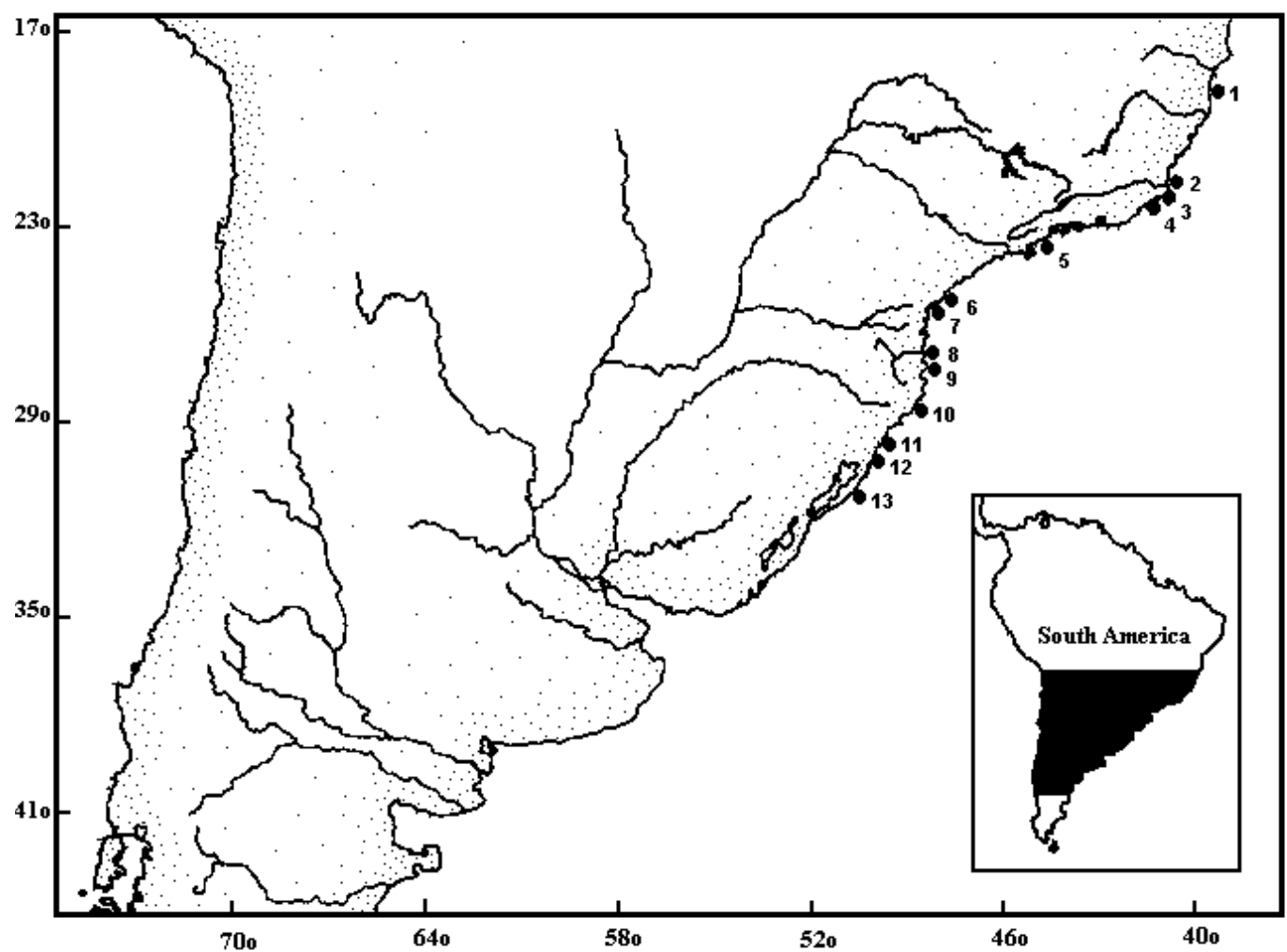

Figure 1. Map showing collecting localities of Pontoporia blainvillei specimens from the Brazilian coast: (1) Guriri, (2) Atafona, (3) Barra do Furado and Farolzinho, (4) Quissamã, (5) Ubatuba, (6) Cananéia, (7) Superagui, (8) Balneário Camboriú, (9) Praia de Canasvieiras and Praia da Joaquina (Florianópolis), (10) Cabo de Santa Marta, (11) Torres, (12) Tramandaí, and (13) Lagoa dos Patos.

Marcus, 1993; Marcus et al., 1996; Monteiro and Reis, 1999).

Traditional Morphometrics - For this analysis, we used 56 adult specimens (30 females and 26 males) of P. blainvillei (see Appendix). We took eight skull measurements, four with a digital caliper (0.01mm precision): GWPO, BNFH, LOS, DFPAC; and the other four with a vernier caliper (0.1mm precision), as the length of these measurements were bigger than 200mm: CBL, LR, CL, ZW (Table 1, Figure 2). We carried out a Principal Components Analysis (PCA) on the covariance matrix for the logarithms of all eight measurements to detect any a priori groups in our sample.
Any groups thus identified were analyzed through a twoway analysis of variance (ANOVA) to test for the effects of population, sex, and the interaction between those variables.

Geometric Morphometrics - The franciscana is one of the smallest cetaceans, with a delicate skull and an extremely long and slender rostrum which can be easily damaged during preparation and handling. For this kind of analysis specimens with whole, unbroken skulls are necessary, so that all the landmarks can be digitized in each image. Therefore we took digital images of 27 skulls (12 females and 15 males) from the total of 56 used in the traditional

Table 1. Skull measurements of Pontoporia blainvillei (abbreviations in parentheses) used in the traditional morphometrics analysis. (See Fig.2)

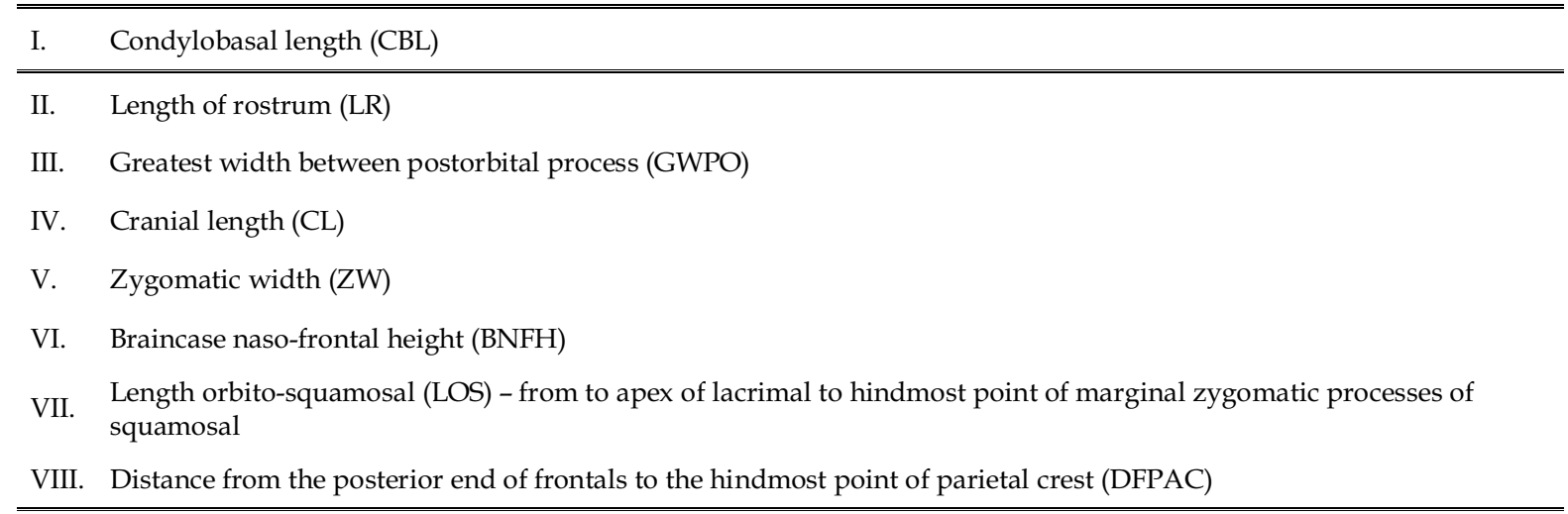


morphometrics analysis. This subset included specimens belonging to each of the two populations detected in the PCA on the linear measurements. Digital images of four views of each skull were taken: dorsal, ventral, lateral and occipital. The images were taken with a Nikon Coolpix 990 digital camera with a resolution of $2048 \times 1536$ pixels, and always included a scale. All images were saved on JPEG format and stored in a CD-ROM. We used the software Tps Utility 1.06 (Rohlf, 2000) to organize the images. Landmarks were digitized using TpsDig 1.30 (Rohlf, 2001a) and are shown on Figure 2, together with specimen orientation. Skulls were aligned by General Procrustes Alignment (GPA) using TpsRelW 1.22 (Rohlf, 2001b) with the options $\alpha=0$, projection orthogonal and include uniform. We saved centroid size to be used as a measurement independent of shape (Bookstein, 1991).

Differences in size (centroid size) between sexes in the two populations were explored using two-way analysis of variance (ANOVA) for all views. Relative warp scores for the ten first relative warps (explaining more than $90 \%$ of the variability in shape) were used in a two-way ANOVA and in a multivariate analysis of variance (MANOVA) to test for sex and population effects in all four views. Relative warp scores were used to represent differences between males and females. All statistical analyses were performed using SAS, SPSS 8.0, and Statistica 5.1.

\section{Results and Discussion}

Traditional Morphometrics - Results of PCA indicate the existence of at least two populations, as can be seen on the graph for the first and second components (Figure 3), in agreement with previous studies by Pinedo $(1991,1995)$ and Secchi et al. (1998). The first PC explains $80 \%$, and the second, $12 \%$ of the observed variability. The first principal component of a PCA on the covariance matrix of the logtransformed data is usually interpreted as "size", while the subsequent components contain both shape and size (Mosimann, 1970; Neff and Marcus, 1980). All loadings for
A

A

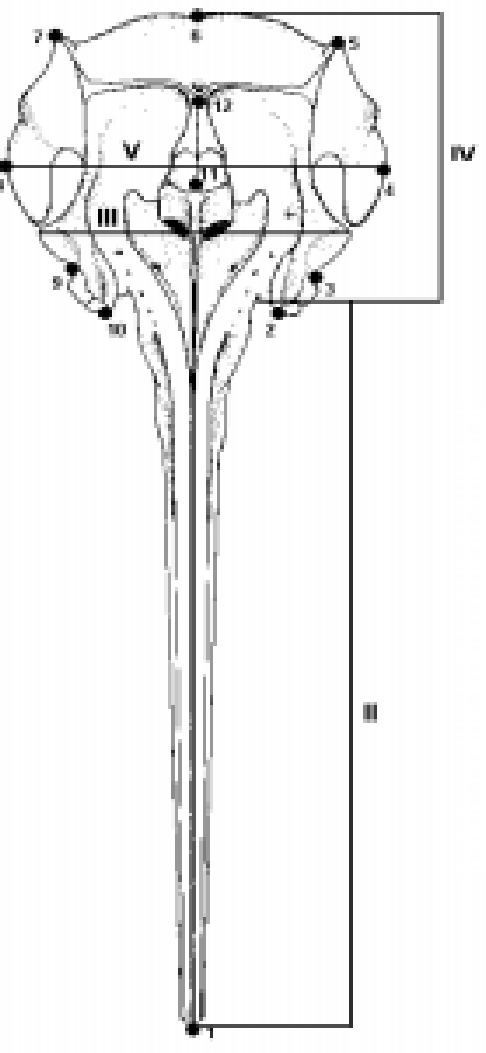

B

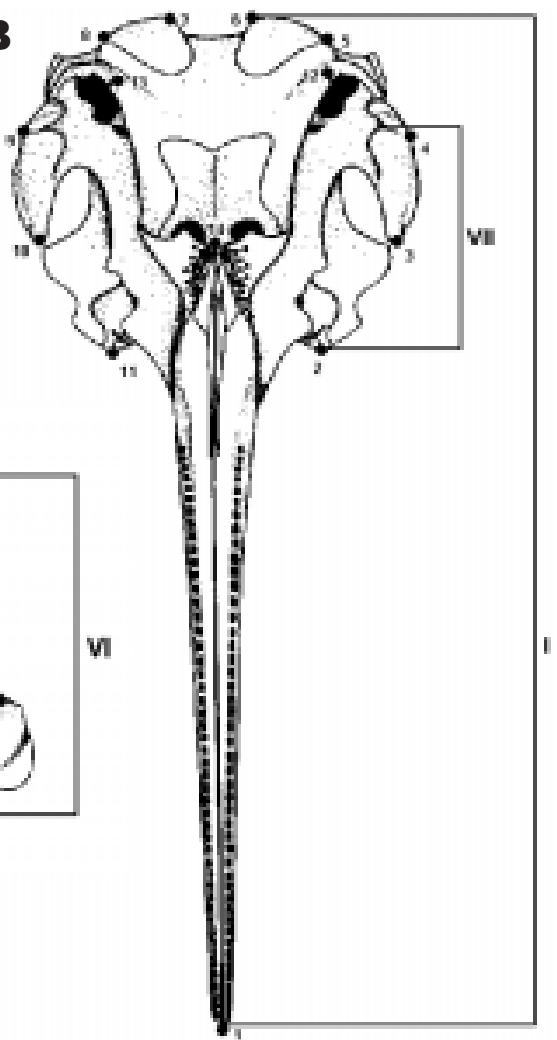

D

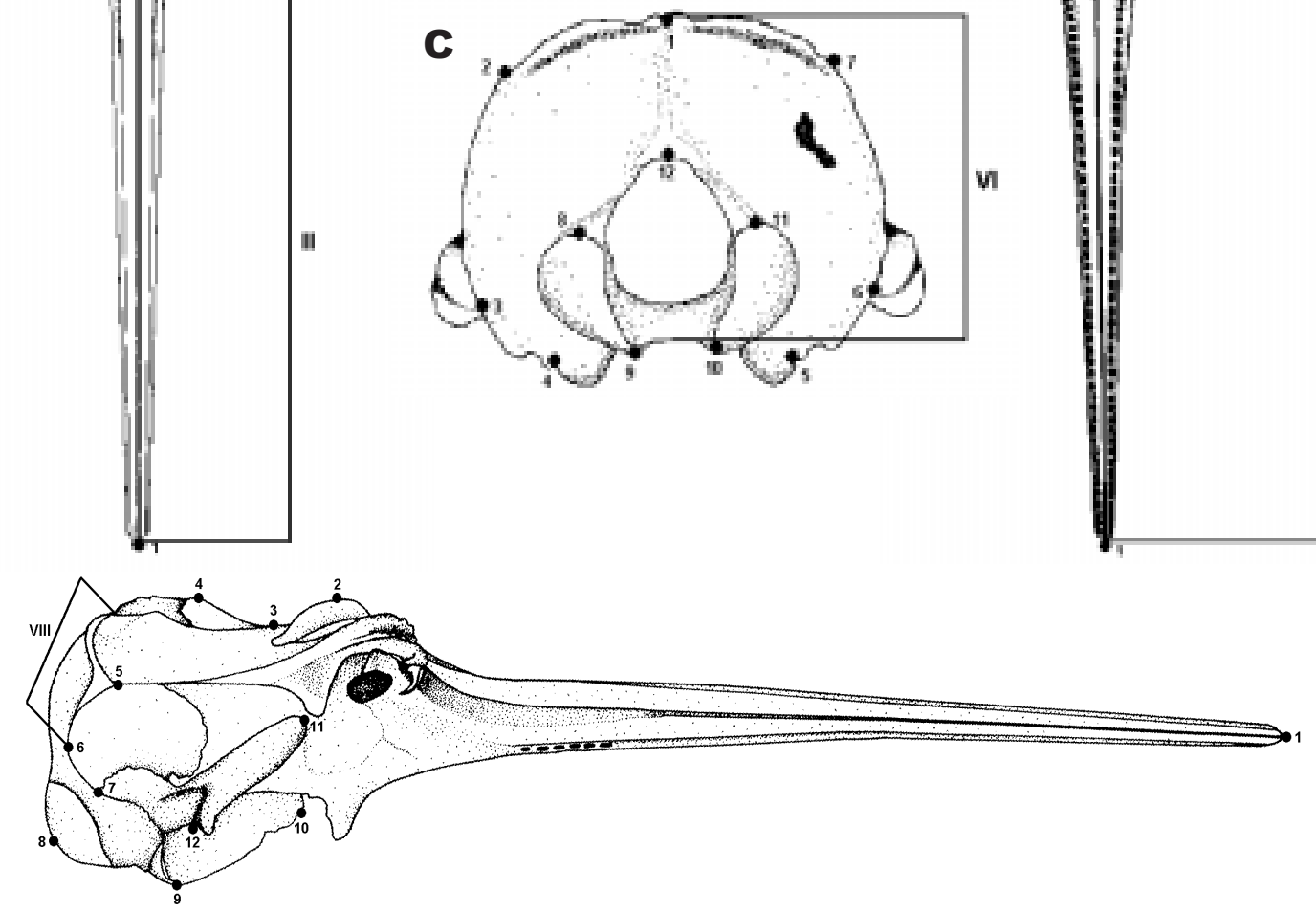

Figure 2. Landmarks (Arabic numerals) and measurements (Roman numerals) for (A) dorsal, (B) ventral, (C) occipital and (D) lateral views of the skull of Pontoporia blainvillei. For definitions of measurements, see Table 1 . 
the eigenvectors of the first PC are positive, corroborating the assumption that this component is representing size in our data. Separation between the two populations is given by a combination of the first and second principal components. Thus, our samples could be grouped in a northern population, comprising specimens from Espírito Santo to Paraná State (localities 1 to 7 , see Figure 1) and a southern population, with specimens from Santa Catarina and Rio Grande do Sul states (localities 8 to 13). Figure 3 shows an apparently discrepant individual, which we grouped with the "southern" sample, although it is clearly morphometrically closer to the "northern" sample. We believe this is not a problem, since it does not disrupt the perceived pattern. Overall, a distinct geographic pattern can de discerned, in accordance with previous published analysis, as discussed above.

Differences between sexes are mainly associated with the first axis (size), with females always bigger than males, a pattern that has already been described in the literature, mainly for external measurements (Kasuya and Brownell, 1979; Pinedo, 1995; Ramos, 1997).

Results of two-way ANOVA for the eight measurements and two populations are summarized in Table 2. All measurements showed significant differences between populations, and also between sexes. No measurement showed an interaction between sex and population. The MANOVA showed similar results (Wilks' $\lambda$, population: d.f. $=8,20 ; F=31.45 ; p<0.001$; sex: d.f. $=8,20 ; F=10.80 ; p<0.001$; population * sex: d.f. $=8,20 ; \mathrm{F}=1.73 ; \mathrm{p}=$ n.s.). These results indicate that differences between sexes are comparable between the two populations.
Geometric Morphometrics - Size, represented by centroid size, showed significant differences between sexes and the two populations, but no interaction in the two-way ANOVA for all four views of the skull (Table 3). Figure 4 shows a diagram representing the distribution of centroid size for each sex and population. The graph represents centroid size only for the dorsal view, but all other views showed a similar pattern. Thus, there are significant differences in size between males and females, and between the populations analyzed, but the pattern showed in the two populations is the same, with females bigger than males. Skulls of specimens from the southernmost population are always bigger than those from the north. This result agrees with findings from the traditional morphometrics analysis and from the literature.

Results of MANOVA for the relative warps (shape) shown on Table 4 indicate the same pattern in all four views of the skull. There are significant differences between populations, but no differences between males and females, and no significant interaction. These results show that all differences observed between males and females are related to size, and differences between the two populations are due to shape changes in the skull.

Scores of the specimens on the first and second relative warp axes are represented on Figure 5. The first and the second relative warps together are explaining $59.88 \%$ of the observed variation for the dorsal view, $60.61 \%$ for the ventral view, $47.45 \%$ for the lateral view and $51.34 \%$ for the occipital view. Note that the differences here observed are only in shape, as any size effect was already removed by the Procrustes alignment.

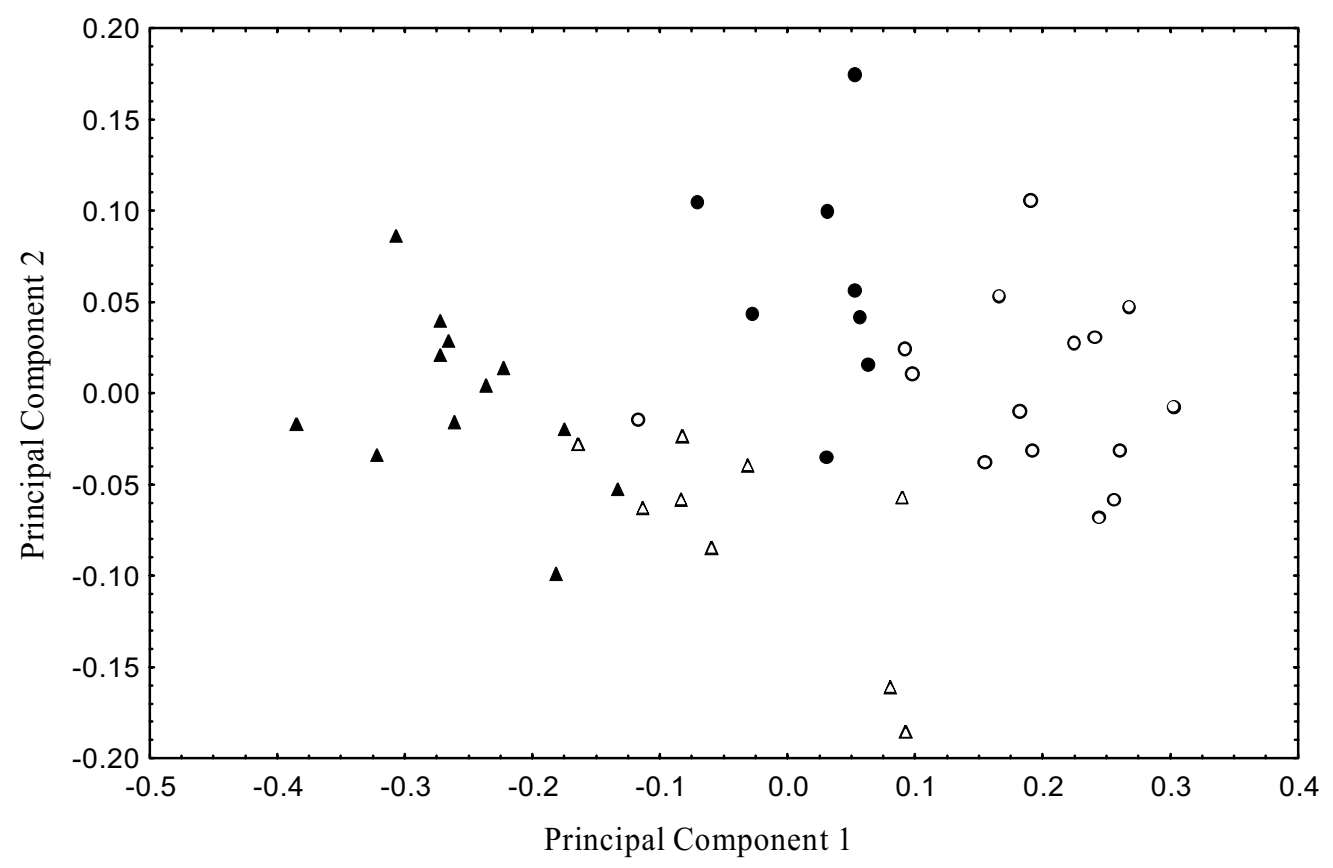

Figure 3. Scores of the specimens of Pontoporia blainvillei belonging to both sexes and two populations in the first two axes of the principal component analysis (PCA). Open symbols, females; closed symbols, males. Triangles represent samples from the northern population and circles indicate samples from southern population. 
Table 2. Results of two-way ANOVA over linear measurements taken from the skull of Pontoporia, showing the effects of population, sex and population * sex interaction.

\begin{tabular}{|c|c|c|c|c|c|c|c|c|c|}
\hline Measurement & & d.f. & $\mathbf{F}$ & p & Measurement & & d.f. & $\mathbf{F}$ & p \\
\hline \multirow[t]{3}{*}{ CBL } & pop & 1 & 75.03 & 0.0001 & $\mathrm{ZW}$ & pop & 1 & 246.47 & 0.0001 \\
\hline & sex & 1 & 64.69 & 0.0001 & & sex & 1 & 44.97 & 0.0001 \\
\hline & pop * sex & 1 & 0.26 & n.s. & & pop * sex & 1 & 1.04 & n.s. \\
\hline \multirow[t]{3}{*}{ LR } & pop & 1 & 38.62 & 0.0001 & $\mathrm{BNFH}$ & pop & 1 & 40.23 & 0.0001 \\
\hline & $\operatorname{sex}$ & 1 & 51.86 & 0.0001 & & sex & 1 & 27.31 & 0.0001 \\
\hline & pop * sex & 1 & 0.3 & n.s. & & pop * sex & 1 & 4.23 & n.s. \\
\hline \multirow[t]{3}{*}{ GWPO } & pop & 1 & 146.58 & 0.0001 & LOS & pop & 1 & 139.81 & 0.0001 \\
\hline & sex & 1 & 20.94 & 0.0001 & & sex & 1 & 16.27 & 0.0004 \\
\hline & pop * sex & 1 & 0.61 & n.s. & & pop * sex & 1 & 0.28 & n.s. \\
\hline \multirow[t]{3}{*}{ CL } & pop & 1 & 105.58 & 0.0001 & DFPAC & pop & 1 & 13.87 & 0.0009 \\
\hline & sex & 1 & 25.49 & 0.0001 & & sex & 1 & 7.16 & 0.0125 \\
\hline & pop * sex & 1 & 0.13 & n.s. & & pop * sex & 1 & 1.81 & n.s. \\
\hline
\end{tabular}

pop $=$ population; n.s. $=$ not significant

Table 3. Results of two-way ANOVA for centroid size in all views of the skull of Pontoporia blainvillei, showing the effects of population, sex and population * sex interaction.

\begin{tabular}{llccc}
\hline View & & d.f. & F & p \\
\hline \hline DORSAL & pop & 1 & 57.03 & 0.001 \\
& sex & 1 & 20.92 & 0.001 \\
& pop * sex & 1 & 1.18 & n.s. \\
& & & & \\
LATERAL & pop & 1 & 61.5 & 0.001 \\
& sex & 1 & 14.55 & 0.001 \\
& pop * sex & 1 & 0.44 & n.s. \\
& & & & \\
OCCIPITAL & pop & 1 & 55.63 & 0.001 \\
& sex & 1 & 11.87 & 0.002 \\
& pop * sex & 1 & 0.09 & n.s. \\
& & & & \\
VENTRAL & pop & 1 & 73.39 & 0.001 \\
& sex & 1 & 25.18 & 0.001 \\
& pop * sex & 1 & 1.9 & n.s. \\
\hline
\end{tabular}

pop = population; n.s. $=$ not significant
Table 4. Results of the MANOVA over relative warp scores representing skull shape in males and females for four views from two populations of Pontoporia blainvillei.

\begin{tabular}{llccc}
\hline \hline View & & d.f. & F & p \\
\hline \hline DORSAL & pop & $10 ; 12$ & 3.67 & 0.018 \\
& sex & $10 ; 12$ & 1.15 & n.s. \\
& pop ${ }^{*}$ sex & $10 ; 12$ & 0.77 & n.s. \\
& & & & \\
LATERAL & pop & $10 ; 11$ & 9.49 & 0.0004 \\
& sex & $10 ; 11$ & 1.42 & n.s. \\
& pop ${ }^{*}$ sex & $10 ; 11$ & 0.69 & n.s. \\
& & & & \\
OCCIPITAL & pop & $10 ; 14$ & 9.10 & 0.0002 \\
& sex & $10 ; 14$ & 0.94 & n.s. \\
& pop * sex & $10 ; 14$ & 1.76 & n.s. \\
& & & & \\
VENTRAL & pop & $10 ; 12$ & 3.49 & 0.0220 \\
& sex & $10 ; 12$ & 1.99 & n.s. \\
& pop ${ }^{*}$ sex & $10 ; 12$ & 1.37 & n.s. \\
\hline \hline
\end{tabular}

pop = population; n.s. $=$ not significant

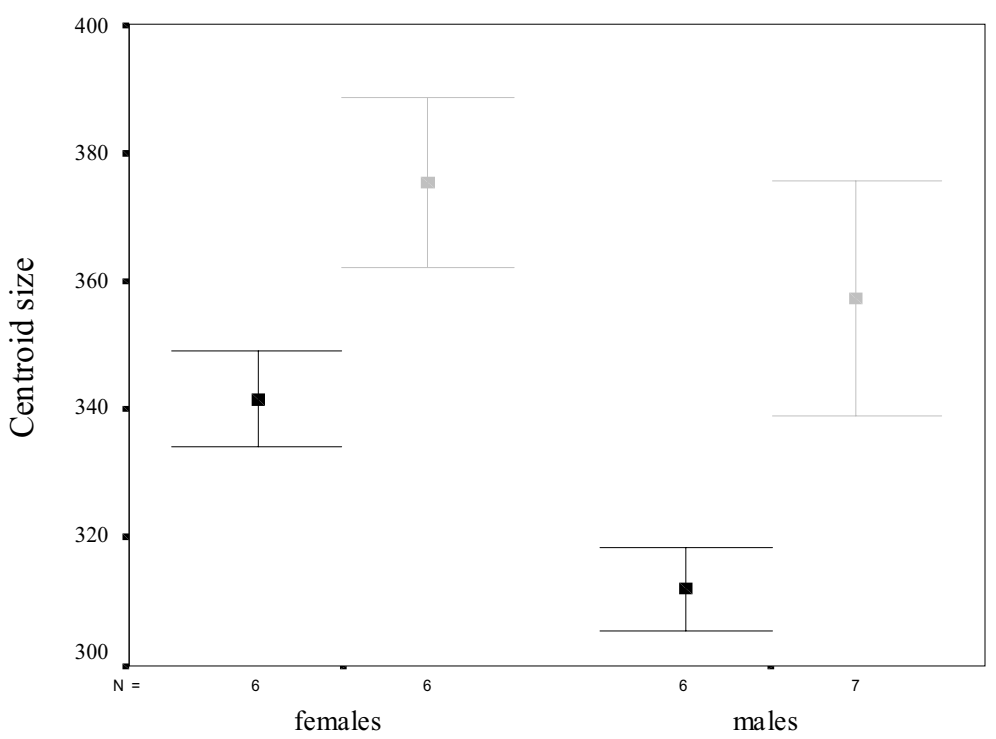

Figure 4. Diagram showing the distribution of centroid size (dorsal view) of the skull of Pontoporia blainvillei for each sex. Black, samples from northern population; gray, samples from southern population. Squares, means; vertical line, $95 \%$ confidence intervals for means. 
a)

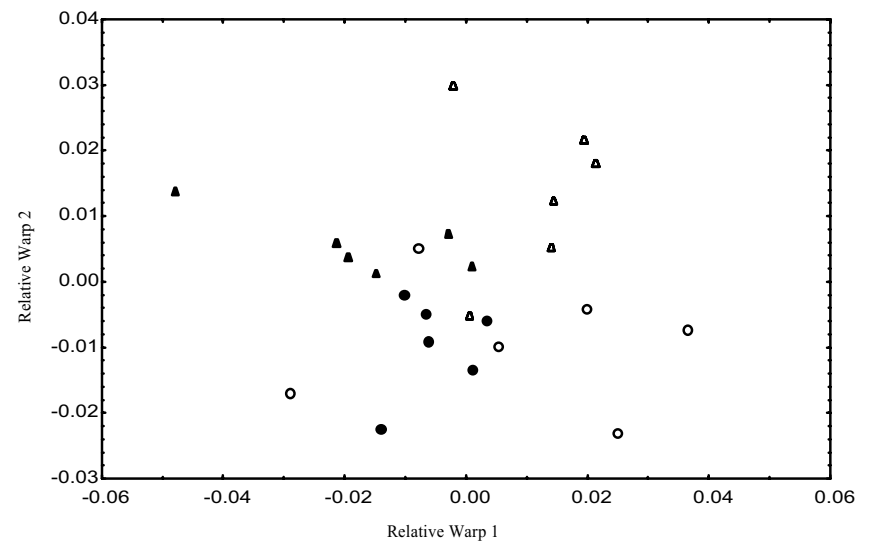

b)

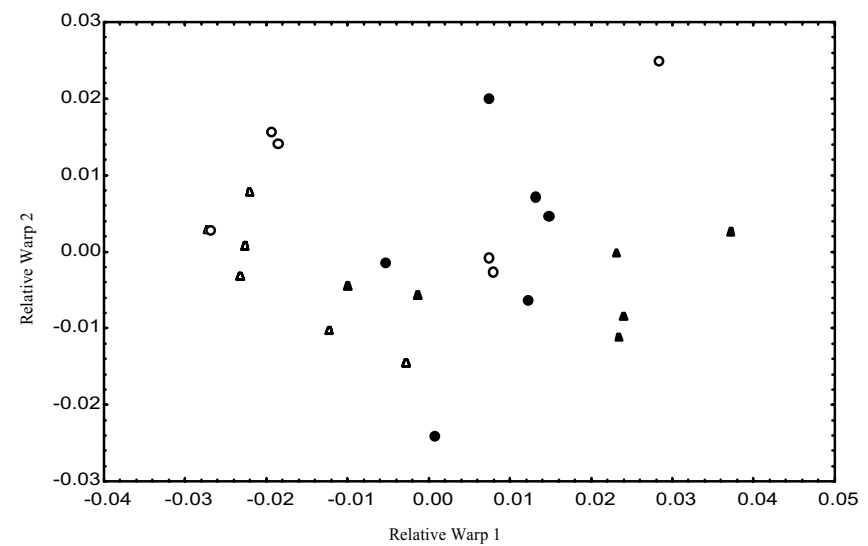

c)

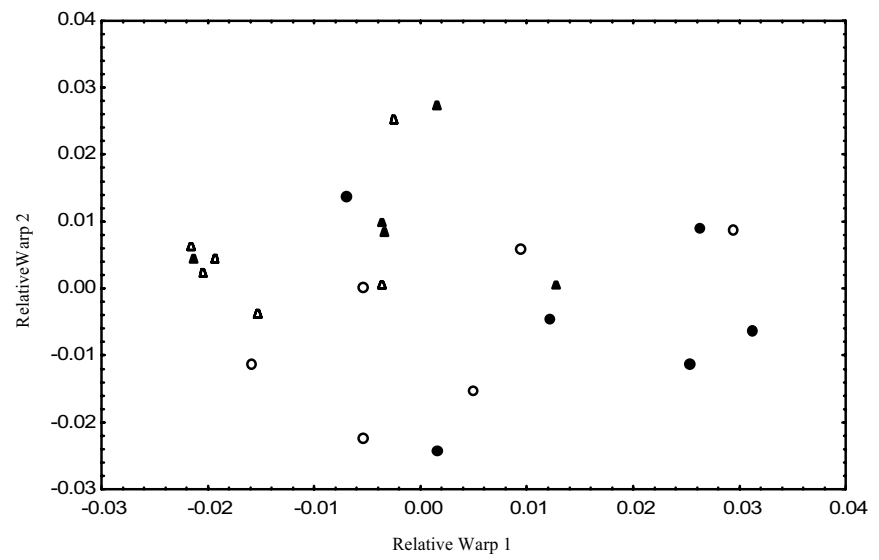

d)

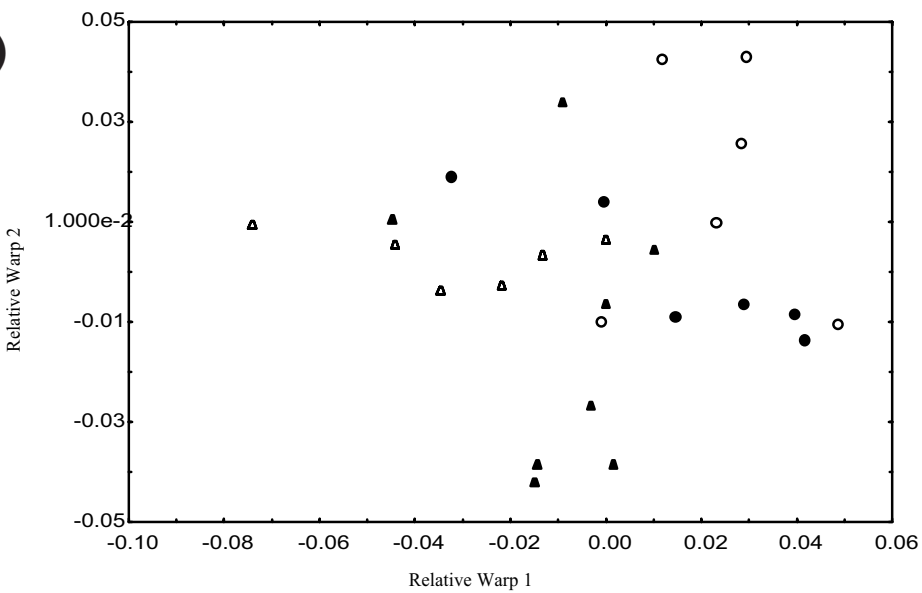

Figure 5. Relative warps scores plot for the skull of Pontoporia blainvillei for (a) dorsal view, (b) ventral view, (c) lateral view and (d) occipital view. Open symbols, females; closed symbols, males. Triangles, samples from the northern population; circles, samples from the southern population. 
Our results show that there is no significant sexual dimorphism in shape, when northern and southern samples are considered separately. However, there is a consistent skull shape variation between the two populations, which agrees with the findings of Pinedo (1991, 1995) and Secchi et al. (1998). Size, however, is an important component separating males from females.

An interesting side issue to our study is that if size is excluded from the analysis, both sexes and also individuals with indeterminate sex from Museum collections may be grouped for further studies of geographic variation.

\section{Acknowledgements}

We thank I.B. Moreno (GEMARS), E.L.A. Monteiro-Filho (IPeC) and P.C. Simões-Lopes (UFSC) for allowing access to the collections under their care. F. Rosas and D. Danilewicz kindly allowed access to their data. The late L. F. Marcus read and criticized the manuscript; for him our deep gratitude. M. Amano, T. Jefferson, S. N. Pedraza and an anonymous referee provided invaluable criticism. This work was supported by FAPESP (grants 01/07053-5, 99/10599-4, 98/05075-7).

\section{References}

Bookstein, F.L. (1991) Morphometric tools for landmark data: geometry and biology. Cambridge Univ. Press, New York.

Bookstein, F.L. (1996) Combining tolls of geometric morphometrics. Pages 131-151 in Marcus, L., Corti, M., Loy, A., Naylor, G.J.P. and Slice, D. (Eds) Advances in Morphometrics. Plenum Press, New York.

Cabrera, A. and Yepes, J. (1940) Los cetaceos. Pages 291-318 in Mamiferos sud-americanos: vida, costumbres y descripción. Compañia Argentina de Editores, Tucuman. (Historia Natural Ediar).

Crespo, E.A., Harris, G. and González, R. (1998) Group size and distributional range of the franciscana, Pontoporia blainvillei. Marine Mammal Science 14(4): 845-849.

Gervais, O. and d'Orbigny, A. (1844) M. Paul Gervais, au nom de M. Alcide d'Orbigny et au sien met sous les yeux de la Société trois planches représentent des Dauphins observés par ce dernier pedant son voyage dans la Amérique Meridionale. Bulletin Société Philomatique de Paris 5(9): 38-40.

Kasuya, T. and Brownell, R.L. (1979) Age determination, reproduction and growth of franciscana dolphin, Pontoporia blainvillei. Scientific Reports of the Whales Research Institute 31: 45-67.

Lahille, F. (1899) Notes sur les dimensions du Stenodelphis blainvillei. Revista del Museo de La Plata 9: 389-392.

Marcus, L.F. (1990) Traditional morphometrics. Pages 77-122 in Rohlf, F.J. and Bookstein, F. (Eds) Proceedings of the Michigan
Morphometrics Workshop. Special Publications, The University of Michigan Museum of Zoology, Ann Arbor.

Marcus, L.F., Bello, E. and Garcia-Valdecasas, A. (1993) Contributions to morphometrics. Monografías del Museo Nacional de Ciencias Naturales, 8, Madrid.

Marcus, L.F., Corti, M., Loy, A., Naylor, G.J.P. and Slice, D. (1996) Advances in Morphometrics. Plenum Press, New York.

Monteiro, L.R. and Reis, S.F. (1999) Princípios de morfometria geométrica. Holos Editora, Ribeirão Preto.

Moreira, L.M. de P. and Siciliano, S. (1991) Northward extension range for Pontoporia blainvillei. Page 48 in Abstracts, Ninth Biennial Conference on the Biology of Marine Mammals, 5-9 December, Chicago.

Mosimann, J.E. (1970) Size allometry: size and shape variables with characterizations of the log-normal and generalized gamma distributions. Journal of the American Statistical Association 65 (330): 930-945.

Neff, N. and Marcus, L.F. (1980) A survey of multivariate methods for systematics. American Museum of Natural History, New York.

Pilleri, G. (1971) On the La Plata dolphin Pontoporia blainvillei off the Uruguayan coasts. Investigations on Cetacea 3: 59-67.

Pinedo, M.C. (1991) Development and variation of the franciscana, Pontoporia blainvillei. PhD Dissertation. University of California, Santa Cruz. 406pp.

Pinedo, M.C. (1995) Development and variation in external morphology of the franciscana, Pontoporia blainvillei. Revista Brasileira de Biologia 55(1): 85-96.

Perrin, W.F. (1975) Variation of spotted and spinner porpoise (genus Stenella) in the eastern Tropical Pacific and Hawaii. Bulletin of the Scripps Institution of Oceanography 21: 1-206.

Ramos, R.M.A. (1997) Determinação de idade e biologia reprodutiva de Pontoporia blainvillei $e$ de Sotalia fluviatilis (Cetacea: Pontoporiidae e Delphinidae) no Norte do Rio de Janeiro. MSc Dissertation, Universidade Estadual do Norte Fluminense, Campos dos Goytacazes. 95pp.

Ramos, R.M.A., Di Beneditto, A.P.M. and Lima, N.R.W. (2000) Growth parameters of Pontoporia blainvillei and Sotalia fluviatilis (Cetacea) in northern Rio de Janeiro, Brazil. Aquatic Mammals 26(1): 65-75.

Rohlf, F.J. and Marcus, L.F. (1993) A revolution in morphometrics. Trends in Ecology and Evolution 8: 129-132.

Rohlf, F.J. (2000) Tps Utility Program, ver. 1.06. ( ) 2000, F. James Rohlf. Dept. Ecology and Evolution, State University of New York at Stony Brook.

Rohlf, F.J. (2001a) TpsDig, ver. 1.30. @ 2001, F. James Rohlf. Dept. Ecology and Evolution, State University of New York atStony Brook.

Rohlf, F.J. (2001b) TpsRelW, ver. 1.22. ( ) 2001, F. James Rohlf. Dept. Ecology and Evolution, State University of New York atStony Brook.

Secchi, E.R., Wang, J.Y., Murray, B.W., Rocha-Campos, C.C. and White, B.N. (1998) Population differentiation in the franciscana (Pontoporia blainvillei) from two geographic locations in Brazil as determined from mitocondrial DNA control region sequences. Canadian Journal of Zoology 76(9): 1622-1627. 


\section{APPENDIX}

List of Pontoporia blainvillei specimens from Brazil examined in this paper (total $=56$ ), with collection information (see localities in Figure 1) about sex and available material: (s) skull, with or without mandibula; (p) postcranial skeleton, partial or complete. Museum acronyms are as follows: MZUSP = Museu de Zoologia da Universidade de São Paulo, GEMARS = Grupo de Estudo de Mamíferos Aquáticos do Rio Grande do Sul, IPeC = Instituto de Pesquisas Cananéia, UFSC $=$ Universidade Federal de Santa Catarina, Laboratório de Mamíferos Aquáticos (LAMAQ).

\section{Espírito Santo State:}

Guriri, São Mateus: MZUSP 28410 오 (s, p).

\section{Rio de Janeiro State:}

Atafona: MZUSP 23794 우 (s, p), 23795 ơ (s, p); Barra do Furado: MZUSP 25651 o' (s, p); Farolzinho: MZUSP 25648 ơ (s, p); Quissamã: MZUSP $256360^{\circ}$ (s, p), 25646 우 (s, p), 25647 ơ $^{\prime \prime}(\mathrm{s}, \mathrm{p})$.

\section{São Paulo State:}

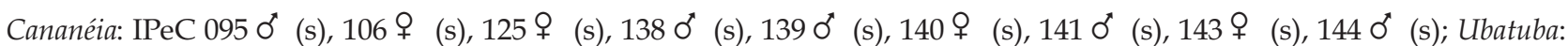
MZUSP $96350^{\prime \prime}(\mathrm{s}, \mathrm{p}), 9636$ ㅇ $(\mathrm{s}, \mathrm{p})$.

\section{Paraná State:}

Superagui: $\operatorname{IPeC} 026$ 우 (s), 028 우 (s); $0300^{\circ}$ (s), $1190^{\prime \prime}$ (s), $1230^{\prime \prime}$ (s).

\section{Santa Catarina State:}

Balneário Camboriú: UFSC 1058 오 (s); Cabo de Santa Marta: UFSC 1214 ơ (s), 1216 오 (s), 1217 우 (s); Praia de Canasvieiras, Florianópolis: UFSC 1121 ㅇ

(s); Praia da Joaquina, Florianópolis: UFSC 1066 우 (s).

\section{Rio Grande do Sul State:}

GEMARS $1580^{\circ}$ (s), $1690^{\circ} \quad$ (s), 253 우 (s), 335 o' (s), 418 우 (s), 547 우 (s), 548 우 (s); Subárea 1 (from Torres to Tramandái):

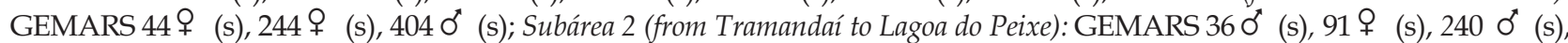

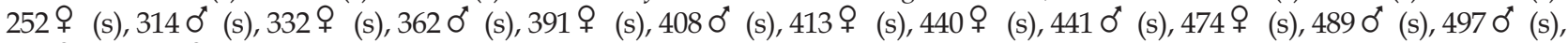
511 우 (s), 572 우 (s) 